\title{
Ottoman Mosques in Albania: Building Acoustic Exploration inside Five Case Studies
}

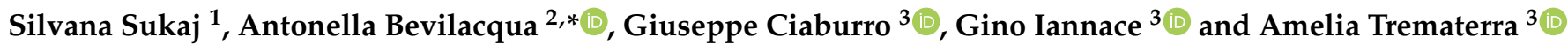 \\ 1 Department of Engineering and Architecture, European University of Tirana (UET), 1000 Tirana, Albania; \\ silvana.sukaj@uet.edu.al \\ 2 Department of Industrial Engineering, University of Parma, 43124 Parma, Italy \\ 3 Department of Architecture and Industrial Design, University of Campania "Luigi Vanvitelli", \\ 81031 Aversa, Italy; giuseppe.ciaburro@unicampania.it (G.C.); gino.iannace@unicampania.it (G.I.); \\ liatrematerra@libero.it (A.T.) \\ * Correspondence: antonella.bevilacqua@unipr.it
}

Citation: Sukaj, S.; Bevilacqua, A.;

Ciaburro, G.; Iannace, G.; Trematerra,

A. Ottoman Mosques in Albania:

Building Acoustic Exploration inside Five Case Studies. Buildings 2021, 11, 430. https://doi.org/10.3390/ buildings11100430

Academic Editor: Francesco Nocera

Received: 8 August 2021

Accepted: 18 September 2021

Published: 24 September 2021

Publisher's Note: MDPI stays neutral with regard to jurisdictional claims in published maps and institutional affiliations.

Copyright: (c) 2021 by the authors. Licensee MDPI, Basel, Switzerland. This article is an open access article distributed under the terms and conditions of the Creative Commons Attribution (CC BY) license (https:/ / creativecommons.org/licenses/by/ $4.0 /)$

\begin{abstract}
The Ottoman mosques of the 15th and 16th centuries represent an architectural typology that has been replicated in territories out of the Middle East for as long as Islam spread its influence on other countries. This paper deals with the determination of the acoustic properties inside a few Ottoman mosques located in different cities of Albania, specifically in Elbasan, Berat, Kavaja, Tirana and Shkodra. A comparison between the prayer rooms of these five mosques has been undertaken in terms of the main acoustic parameters by following the standard requirements outlined in ISO 3382-1. The architectural characteristics of the single-unit mosques chosen for this research study are determined by the domed-square musalla, which has a comparable volume size among all five mosques. Results gathered by the acoustic measurements undertaken in unoccupied conditions highlight an overall lack of speech understanding given the values of some acoustic parameters fairly acceptable. This outcome is justified by the geometrical configuration, worsened by the presence of a dome that creates a focusing effect of the sound rays, and by the reflecting finish materials applied to walls and roof that facilitate the build-up defect of echoes.
\end{abstract}

Keywords: Ottoman mosques; single-unit mosques; musalla; acoustic measurements; architectural acoustics

\section{Introduction}

The acoustics of the mosques have been already taken in consideration by previous research studies in relation to speech intelligibility [1-4]. The compositions of its volume, reasonably simple for the single-unit typology and very elaborate for the cross axial and multi-unit design, has been subject to deep analyses for the presence of reflecting surfaces on walls, other than for the presence of semispherical domes that accentuate the unbalanced distribution of the sound energy across all the space $[5,6]$.

The aim of this paper regards the acoustic analysis of five Balkan mosques, built during the 15th and 16th centuries in different cities of Albania. The characteristic feature of being provided with a unique domed-square prayer room is the common key factor of the selected buildings [7-16]. By undertaking acoustic measurements by using the same equipment and methodology for all the mosques [17-22], a comparison of the main acoustic parameters has been performed. The religious functions, also involving the prostration during prayers, contributed to determining the application of absorbing materials on the floor (i.e., carpet) and reflecting surfaces, such as walls and dome (e.g., plaster, stuccos, etc., on stone/masonry structures) [23,24]. Furthermore, the geometry of the prayer room, composed of a semispherical dome on a squared-base parallelepiped, governs the direction of the sound rays to be focused on certain points. This phenomenon is one of the factors that contribute to the lowering of speech intelligibility inside the musalla $[25,26]$. 
The investigation undertaken by the authors selects five Albanian mosques having comparable volume size and similar dimensions of the squared prayer rooms. The outcomes highlight a lack of speech understanding, especially at low frequencies [27-31]. Future research studies have been introduced to balance the response across the frequency spectrum and apply some acoustic treatments where the simulations will detect the surface areas that contribute to arise echoes and focalization defects [32-38].

\section{Holy Meaning of a Mosque}

The Islamic mosque is a particular building type of architecture which no established design standards exist for its construction [5]. However, the organization of the volume can be understood by the activities executed inside [5]. One of the first word that can help to understand the meaning of this place is masjid (place of prostration) that characterizes the mosques from churches and synagogues because of the act of prostration [5-7]. Another symbol that identifies the mosques from an urban context of a city is the qiblah (main axis) which determines the orientation of the building to be facing Makkah [2]. The Qur'an provides no clear rules regarding how the mosque should have the aesthetics; however, they are not built by following any of the divine patterns [6]. The three main patterns developed in Muslim art are the following [7]:

- Arabesque design, deriving from North Africa and evoking plant configurations;

- Arabic calligraphy;

- Repetition in modules of a specific geometric pattern.

Other than the musalla (sanctuary), the baseline spaces that are of paramount importance for the constitution of a mosque include an open courtyard for the outdoor activities, a library, workroom, classrooms and a kitchen [7]. These places are organized in such a way to distinguish the ritual from the profane areas [6].

By focusing on the musalla, the plan layout of the sanctuary is usually designed to fulfil the performance of communal worship [6]. The harmony, scale and balance of the musalla should guarantee the straight lines of the congregants without interrupting the religious functions [5]. Therefore, large vaults and open spans represent the preferred structural typologies to enable social inclusion [6,7]. The requirements for salat (prayer) include a clean, carpeted floor where standing, bowing, prostration and sitting acts can be performed [7], as shown in Figure 1.

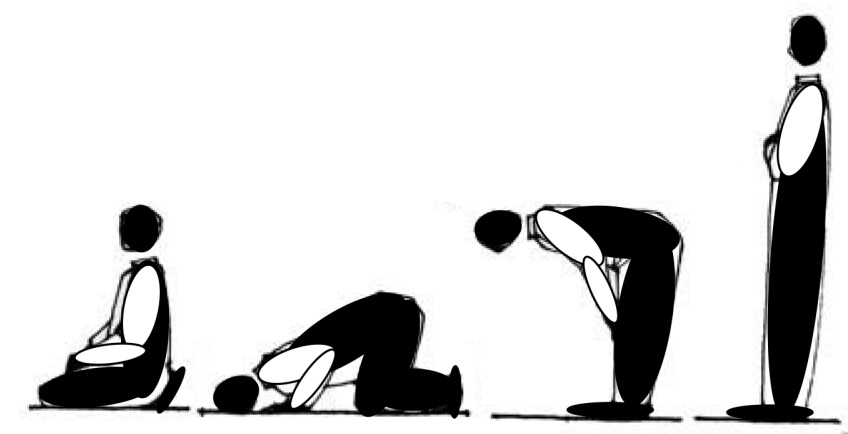

Figure 1. Postures of prayers.

The estimating area to each person is $0.8 \times 1.2 \mathrm{~m}$. On this basis, the total occupancy inside a musalla is generally 500 congregants, against 1000 and 1500 of an urban mosque and an Islamic center, respectively [7].

In Islamic art the circle represents a universal continue, strictly related to the geometry of the line. The circled domes built at the center of the musalla mirror the expression "God is a circle whose circumference is everywhere and whose center is nowhere" [7]. 


\section{The Architectural Features of a Single-Unit Mosque}

The five buildings in comparison dealt with in this paper fall into the typology of a single-unit mosque, having the characteristic features reflecting the domed-square structure, typical of the early Ottoman architecture [6]. The walls of the mosques are generally made of cut stones placed between courses of bricks [7]. The solidity of the masonry is broken only by small windows or doors for ventilation and air change reasons [7].

The presence of a dome completely dominates the indoor space leading towards the center [5]. The domed-square structure is usually completed with a porched courtyard and a minaret, characterizing the basic mass of the typical single-unit mosque widely spread in Turkey even today [7]. A typical example of the architectural organization of a single-unit mosque is shown in Figure 2.

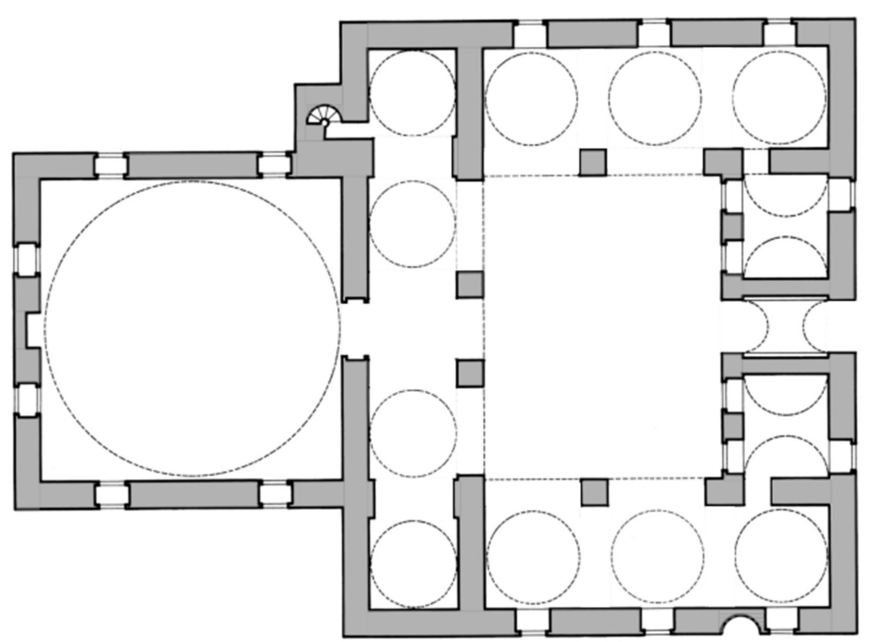

Figure 2. Plan layout of a typical single-unit mosque provided with a courtyard. Basci Ibrahim in Bursa.

The development of the system, from hemispherical brick dome to the squared base, has gone through the transition from octagonal base to polygonal structure [6]. The addition of a courtyard before entering the sacred space is considered an evolution of the single-unit layout by leaving intact the domed-square volume, separated from the other profane places [6].

The spread of Muslim out of the Middle East boundaries developed the construction of single-unit mosques also inside the Balkan peninsula, especially when Albania had been conquered by Turkish sultans during the 17 th century.

\section{Historical Background and Architectural Characteristics}

\subsection{Mosque of Naziresha in Elbasan}

Naziresha is the oldest mosque built in Elbasan in the 1590s, during the flourishing period of the Sultan Mehmed II [8]. Elbasan is located in Southern Albania and the mosque has been built just at the borders of the medieval city in 1599 [7]. It is a purely single-unit mosque, composed of a prayer hall and a minaret located at the south-west corner, it had been damaged on the upper termination but then entirely restored after a requalification of the site. The musalla is a squared planned volume, having internal dimensions of $9 \times 9 \mathrm{~m}$. The semicircular dome has a center height of $13.9 \mathrm{~m}$, with a total volume of approximately $954 \mathrm{~m}^{3}$. Figure 3 reports the plan and the elevation of the mosque. 

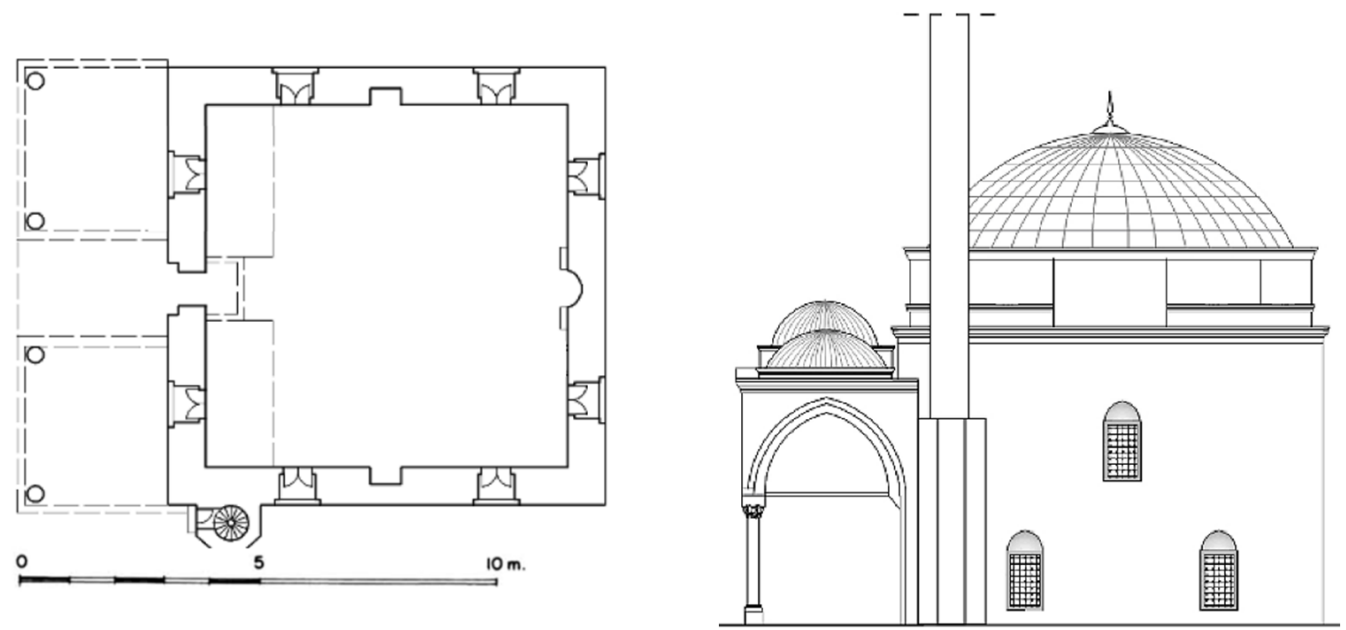

Figure 3. Plan layout (left) and elevation (right) of the Naziresha Mosque in Elbasan. Provision courtesy from Arch. Arsim Murseli, UBT University, Pristina, Kosovo.

The mosque has been recently restored as a whole by taking the occasion of the reconstruction of the upper part of the minaret. Externally the walls are composed of stone until $8.12 \mathrm{~m}$ height, while the brick walls called pendentives are those triangular shoulders that make the transition from a cube to a dome [6]. The dome is composed of $0.9 \mathrm{~m}$ thick brick structure, covered by metal sheets to be protected from the meteorological conditions. The interior design has plaster on the walls and roof, and carpet on the floor. Figure 4 shows some external views of the Naziresha Mosque.

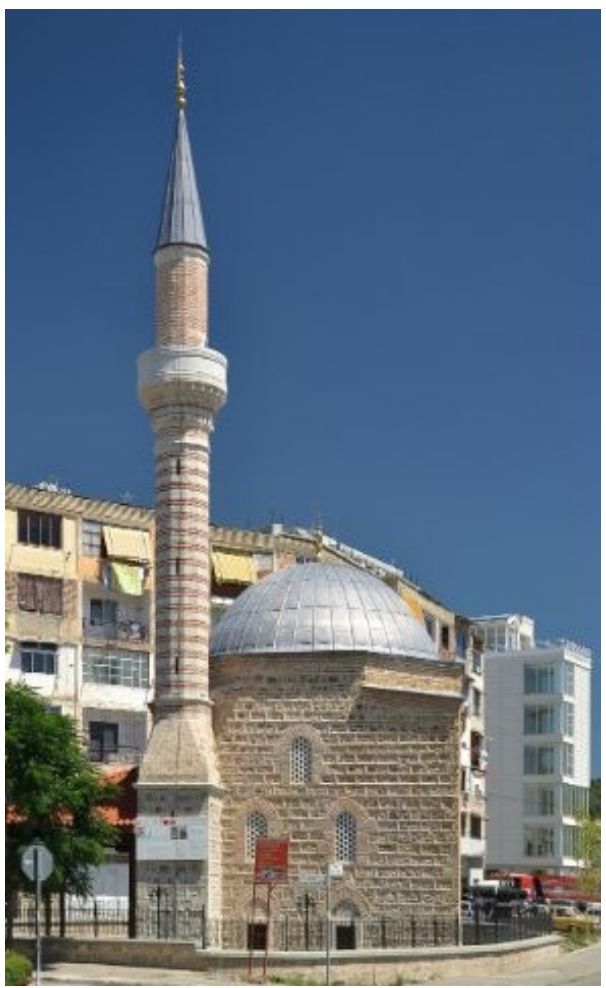

Figure 4. Views of the Naziresha Mosque after the restoration works [9].

\subsection{Lead Mosque in Berat}

The Lead Mosque has been built by the local feudal Ahmed Bey Uzgurliu in the 16th century (1553-1554) in the center of Berat, specifically about Vakef [5]. Berat, or Arnaut Belgrade, is a city dominated by Byzantine monuments. The mosque has been built with 
carved stones applied also to the elegant minaret [6]. The prayer hall is a squared planned volume, having internal dimensions of $10.2 \times 10.2 \mathrm{~m}$. The musalla is surmounted by a semicircular dome having a center height of $14.4 \mathrm{~m}$. The main volume, that is approximately $1307 \mathrm{~m}^{3}$, is lighted by windows located at three orders of height. The geometric transition between the great dome and the cubic hall consists of an octagonal cylinder. The mosque also has a porch with a vaulted roof composed of four little domes of different diameter, the larger placed on the sides while the smaller are at the center of the main axis. Figure 5 shows the plan and the longitudinal section of the mosque.
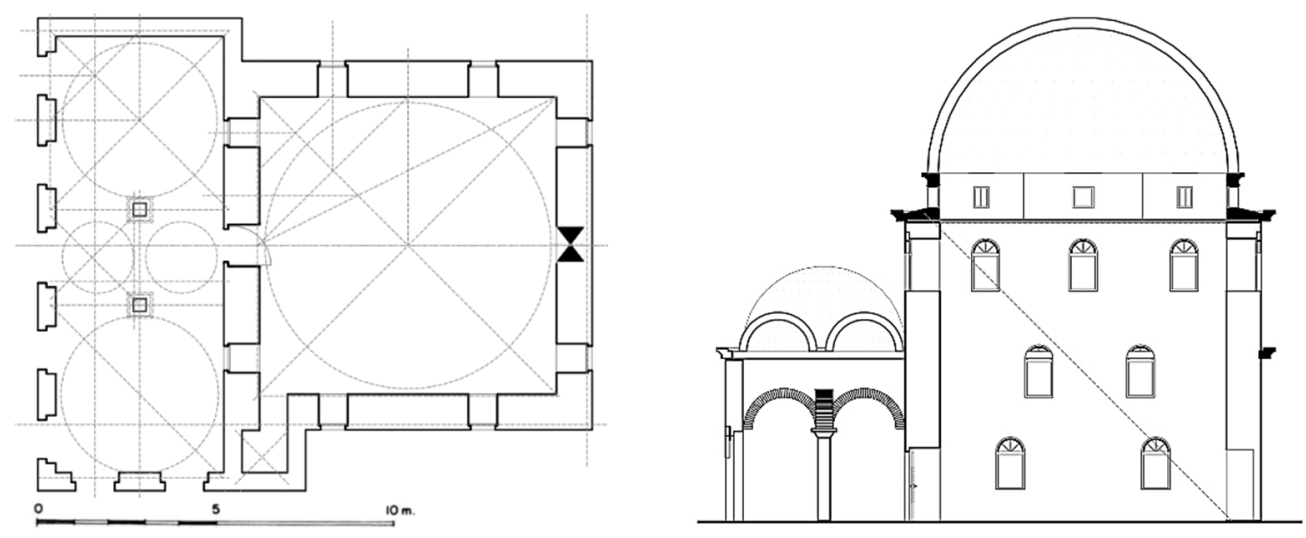

Figure 5. Plan layout (left) and section (right) of the Lead Mosque in Berat. Provision courtesy from Arch. Arsim Murseli, UBT University, Pristina, Kosovo.

The masonry of the external walls has been built by following the cloisonné technique [7], which consists of two horizontal rows of bricks placed between the rows of stones, all plastered on the inner side. Another material used for indoor is the carpet on the floor.

The minaret of the Lead Mosque of Berat has been built with the same construction technique, terminating at the top with a cauldron as a typical characteristic of all the 16th century mosques [8].

Refurbishment works occurred in 1720, when the prayer room was plastered using a reddish lime [8]. Currently, the interior design follows floral motifs while the exterior is dominated by the structural construction of the cubic volume, as shown in Figure 6.

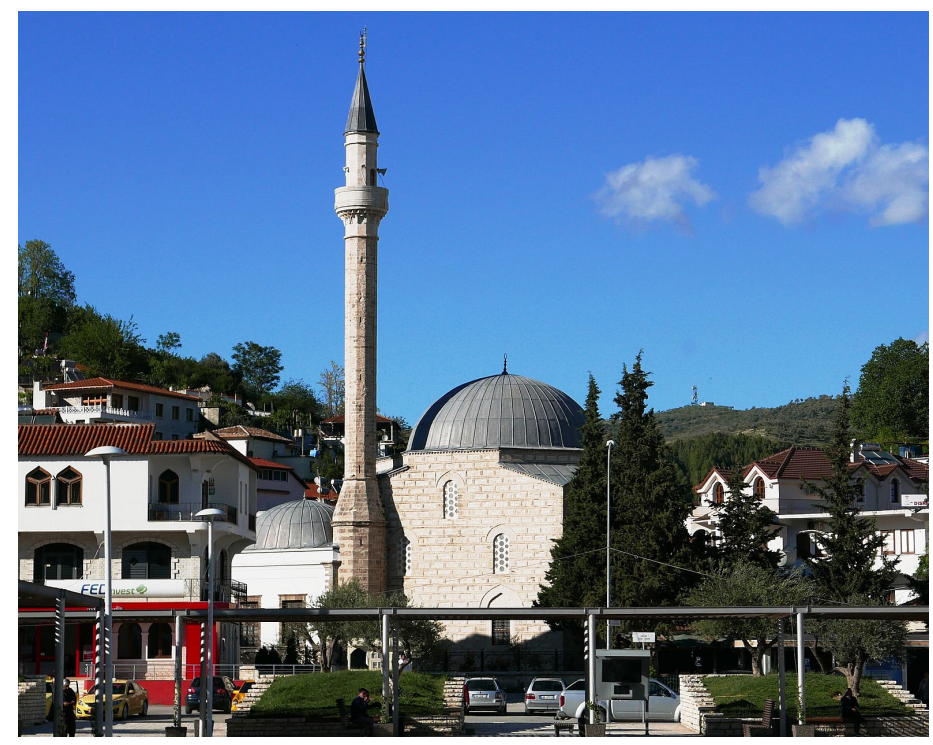

Figure 6. View of the Lead Mosque of Berat [10]. 


\subsection{Kubelie Mosque in Kavaja}

The Kubelie Mosque has been built in 1735-1736 by the Ottoman Kapllan Beu in the center of the medieval market [6]. The architectural characteristic of this mosque is the courtyard placed before the prayer room, composed of five arcades in front and three arcades on each side [8]. Originally, this portico should be covered by a sloped wooden roof. The columns with the Corinthian style were built with the purpose of evoking European architecture [8]. The prayer room has a squared layout in plan, having dimensions of $8.6 \times 8.6 \mathrm{~m}$. The mihrab is placed on the southern side of the musalla. The geometric transition between the great dome and the cubic hall consists of an octagonal cylinder, as shown in Figure 7.
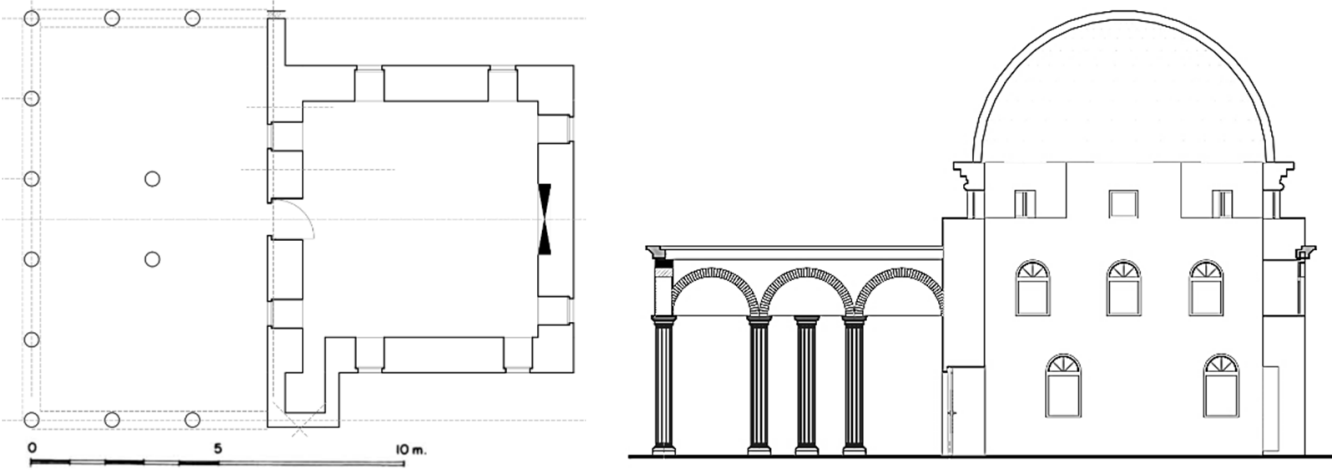

Figure 7. Plan layout (left) and section (right) of the Kubalie Mosque in Kavaja. Provision courtesy from Arch. Arsim Murseli, UBT University.

The height at the center of the dome is $10.5 \mathrm{~m}$, and the total volume of the musalla is $691 \mathrm{~m}^{3}$. The minaret of the Kubelie Mosque has a hexagonal-base pedestal, as shown in Figure 8.

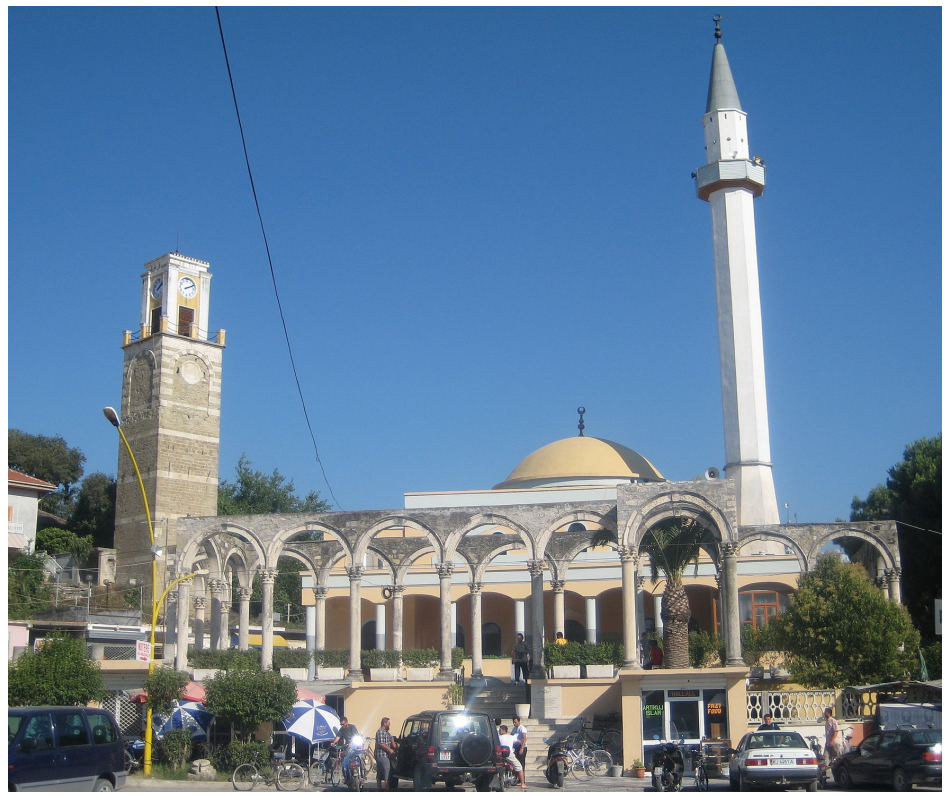

Figure 8. View of the Kubalie Mosque of Kavaja [11].

\subsection{Et'hem Bey Mosque in Tirana}

The Et'hem Bey Mosque has been built in 1793-1794 by Mulla Beut and was completed in 1823 by his son Haxhi Ethen Bey, which is where the name comes from [7]. This mosque also has a minaret and a portico around two sides of the prayer room. The portico is 
currently supported by very solid stone columns. Probably the initial design included into Mulla Bey's project would indicate wooden pillars instead, but no documents nor other indications confirm this hypothesis [8]. The musalla has dimensions of $10.5 \times 10.5 \mathrm{~m}$ and the entire volume is lighted by windows organized onto three different levels. The height at the center of the dome is $14.4 \mathrm{~m}$ and the entire volume of the prayer room is $1394 \mathrm{~m}^{3}$. The access to the prayer room is given by three doors, while the mihrab has been placed in front of the central door, on the opposite side.

The prayer room, the minaret and the portico are interconnected, as shown in Figure 9. The interior design is composed of plaster on the walls and roof, and carpet on the floor. The minaret was composed of regular stone blocks having at the top the cauldron designed by following the style of 16th century mosques [6]. The whole holy site has been terminated in 1821, confirmed by the inscriptions found on the inner side of the mosque [7].
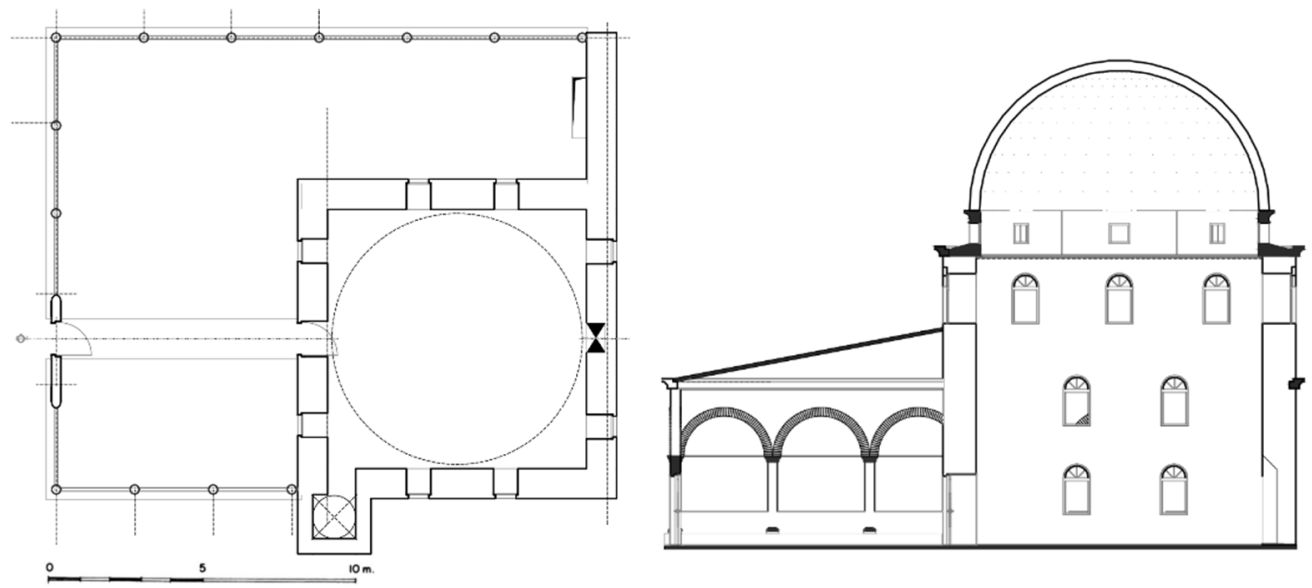

Figure 9. Plan layout (left) and section (right) of the Et'hem Bey Mosque in Tirana. Provision courtesy from Arch. Arsim Murseli, UBT University.

The interior design is characterized by floral motifs represented on walls and dome surface. The chosen colors, between red and green, contribute to make the holy place warm, as shown in Figure 10.

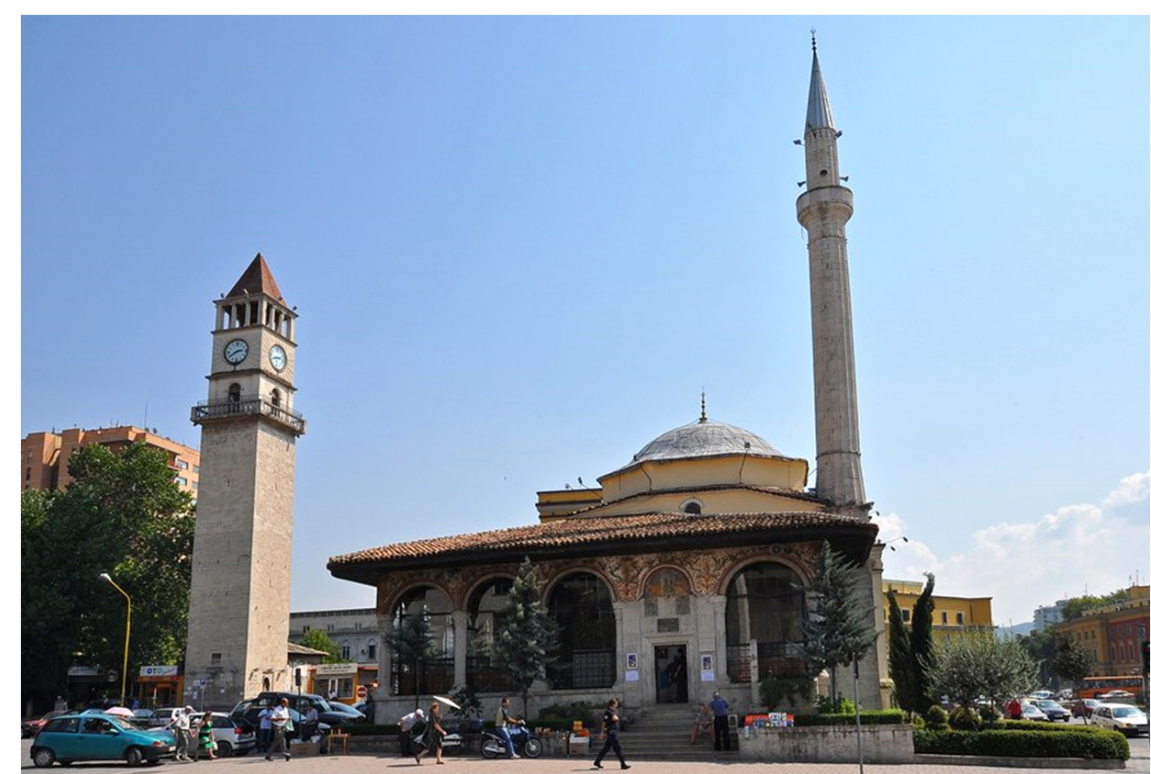

Figure 10. External view of the Et'hem Bey Mosque in Tirana [12]. 


\subsection{Lead Mosque in Shkodra}

Shkodra is considered the most important city of Northern Albania because of its long history. The mosque of Lead is one of the best preserved in Albania, showing evident features of the typical Ottoman style [7]. The design of this mosque evokes the early 15th centuries Muslim buildings realized in Turkey, especially for its geometry of the plan and the volumetric composition of all the complex. Erected in 1774, the musalla of the Lead Mosque is a domed volume having a squared base of $9.2 \times 9.2 \mathrm{~m}$, while the total height taken at the center of the dome is $14.7 \mathrm{~m}$. The hemispherical dome is made of a brick masonry and rests on an octagonal cylinder. Three windows are open on each side of the lateral walls and three doors give access to the sanctuary. The total volume of the prayer hall is approximately $1051 \mathrm{~m}^{3}$. Figure 11 shows the plan and the side elevation.
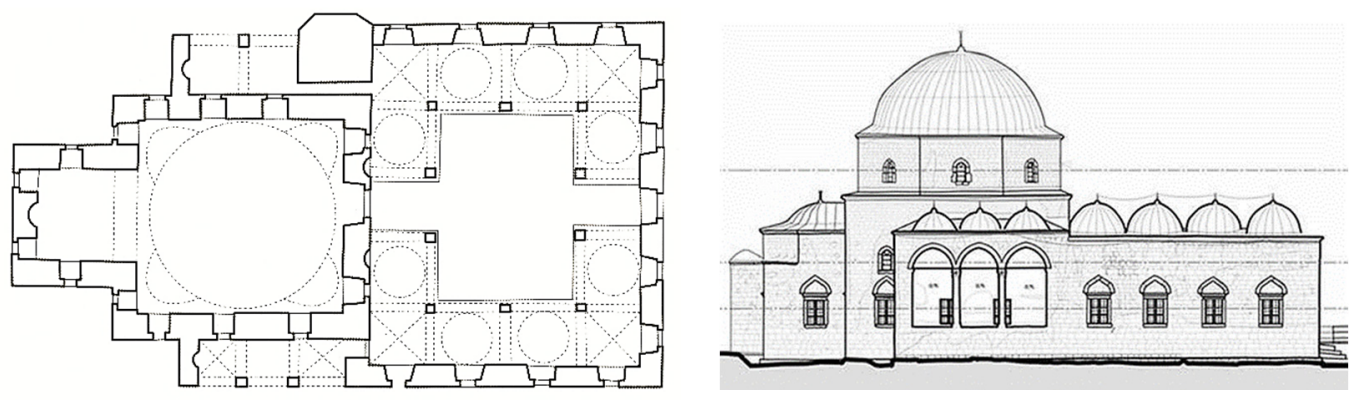

$\circ$

Figure 11. Plan layout (left) and elevation (right) of the Lead Mosque in Shkodra. Provision courtesy from Arch. Arsim Murseli, UBT University, Pristina, Kosovo.

The indoor finish materials of the musalla are plaster on the walls and roof, and carpet on the floor. The courtyard represents the mandatory path to cross before entering the musalla. The courtyard is composed of 12 little domes, corresponding to each arcade having same width. Figure 12 shows the views of the mosque, from outside the entire complex and inside the courtyard.
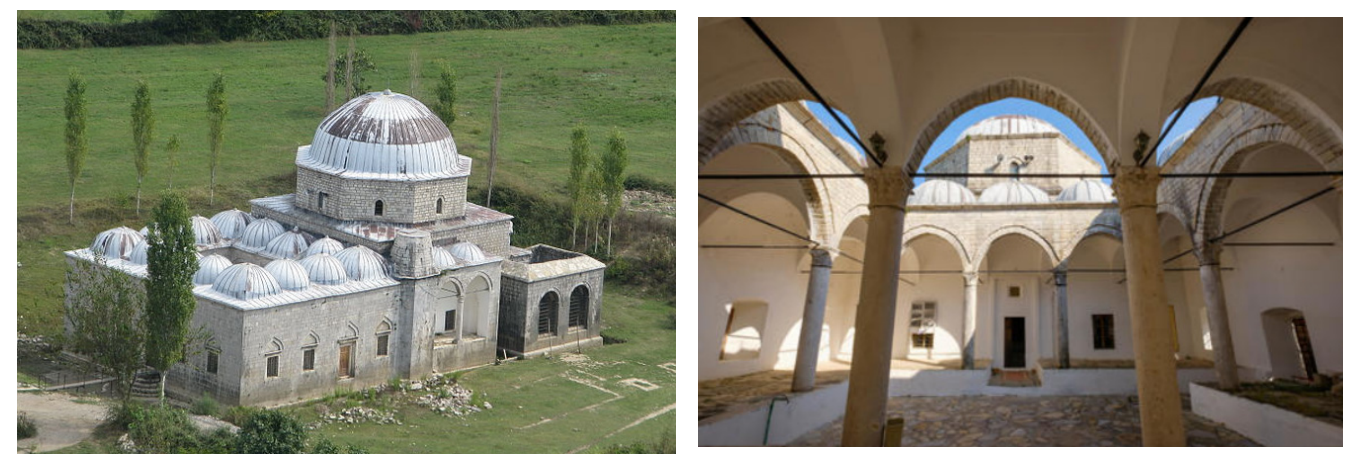

Figure 12. Perspectival views of the Lead Mosque in Shkodra [13].

\subsection{Summary of the Architectural Features}

In the previous subsections all the five selected mosques have been described in detail. Only the Lead Mosque of Shkodra is particularly complex due to the presence of a courtyard. The other four mosques are only composed of the prayer room and an arched portico on the access side. A comparison between all the mosques has been made in terms of architectural characteristics of the prayer room, as summarized in Table 1. 
Table 1. Architectural features of the selected mosques.

\begin{tabular}{cccccc}
\hline Description & Elbasan & Berat & Kavaja & Tirana & Shkodra \\
\hline Musalla dimensions $(\mathrm{m})$ & $9 \times 9$ & $10.2 \times 10.2$ & $8.6 \times 8.6$ & $10.5 \times 10.5$ & $9.2 \times 9.2$ \\
Height of dome $(\mathrm{m})$ & 13.9 & 14.4 & 10.5 & 14.4 & 14.7 \\
Total volume $\left(\mathrm{m}^{3}\right)$ & 954 & 1307 & 691 & 1394 & 1050 \\
Presence of courtyard & No & No & No & No & Yes \\
\hline
\end{tabular}

The interior design of all the mosques was very similar: carpet on floor, plaster on walls and minimal furniture, as shown in Figure 13.

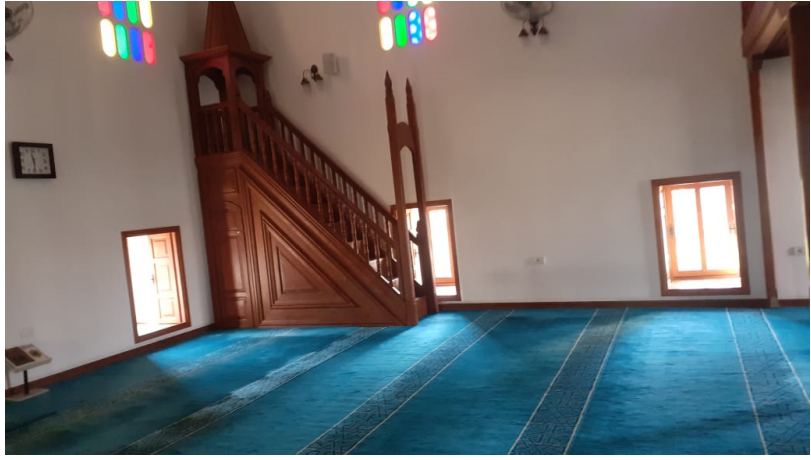

(a)

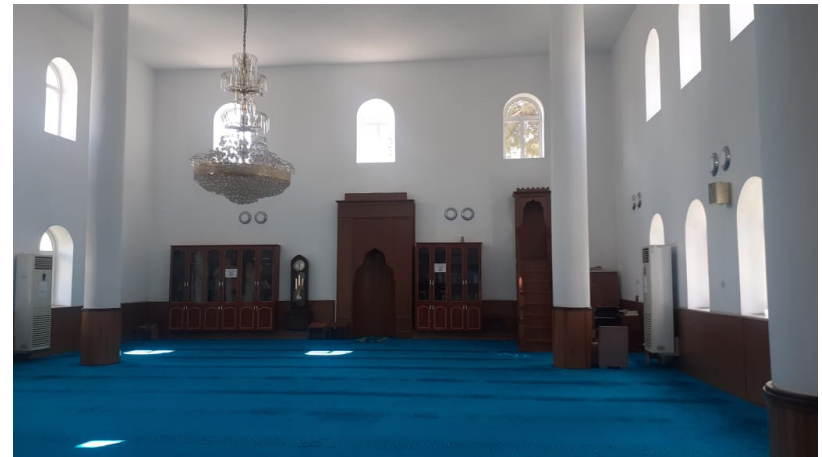

(b)

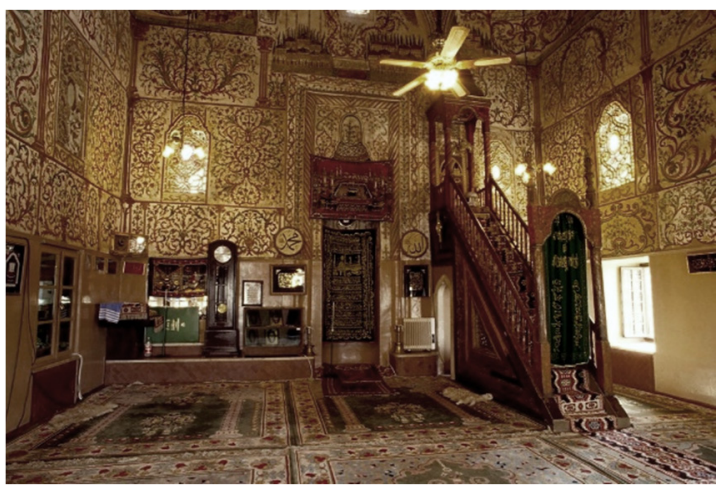

(c)

Figure 13. Example of interior design inside the selected mosques: internal views of (a) Naziresha Mosque of Elbasan, (b) Kubalie Mosque of Kavaja, (c) Et'hem Bey Mosque of Tirana.

\section{Measurements}

A few campaigns of measurements have been undertaken inside the five mosques in order to analyze the acoustic behavior of these architectural typology constructions. The following equipment has been used:

- $\quad$ Balloon pops [14,15];

- $\quad$ Omnidirectional microphone (BRAHMA) [17].

This is a digital four channels microphone that allows to covert the recording in an Ambisonics B-format through the use of the software Brahmavolver $[9,10]$. The composition of the four microphones is arranged in a tetrahedral array and it allows converting the native format into orthogonal sound records during the post-processing [16].

The balloon pops represent a type of sound source affected by the uncertainties of repeatability and directivity [17-19]. Furthermore, the balloon diameter should be wide enough to abundantly cover the low frequencies. The other concern riced by the use of balloon pops is the directivity, resulting in quite a robustness in some directions. Although the excitation signal has a spectrum bandwidth more limited than any electronic signal 
(e.g., Exponential Sine Sweep (ESS), etc.), the survey has been carried out in accordance with the standard requirements outlined by ISO 3382-1 [20].

In each mosque, the sound source location has been selected to be close to the mihrab, where the balloons were burst at the height of $1.3 \mathrm{~m}$ from the floor, while the microphone was placed in different positions across the musalla at the height of $1.3 \mathrm{~m}$ [21]. The receiving positions were five in each mosque, as shown in Figure 14.

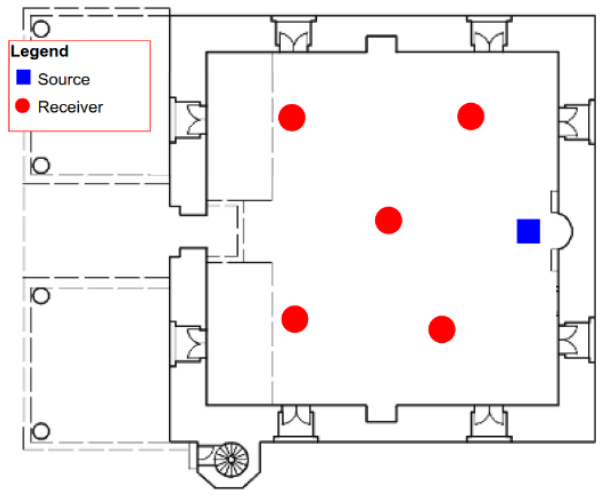

(a)

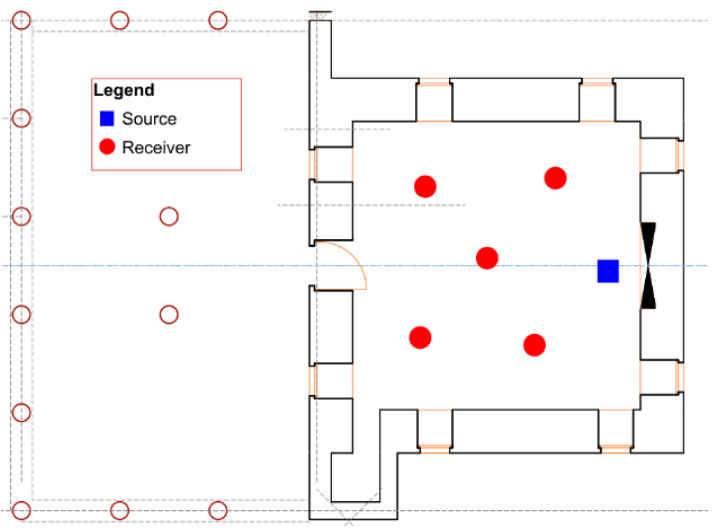

(c)

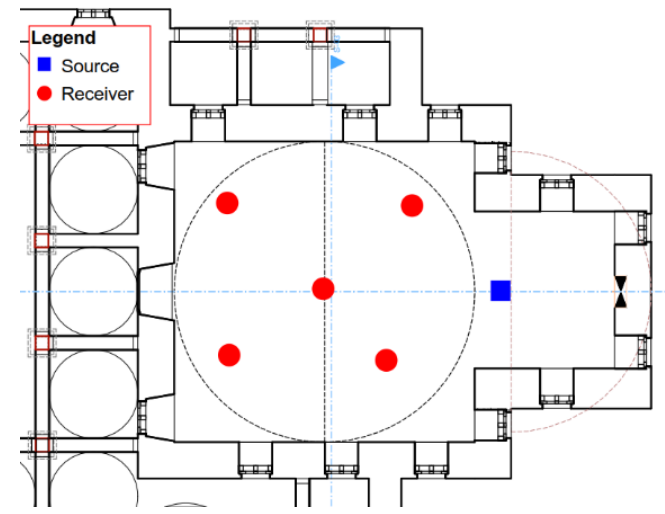

(e)

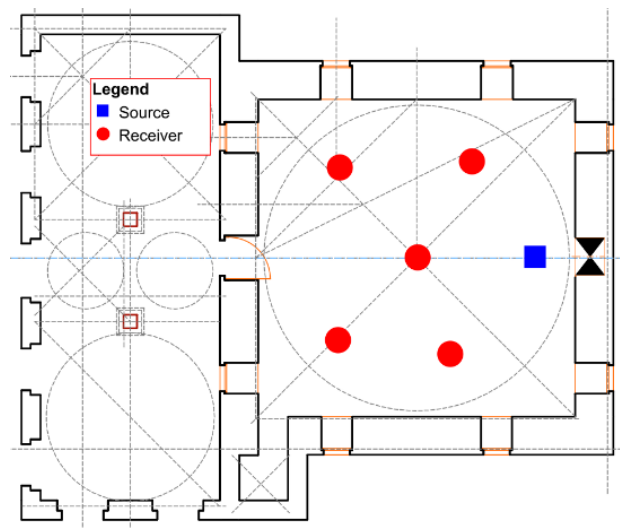

(b)

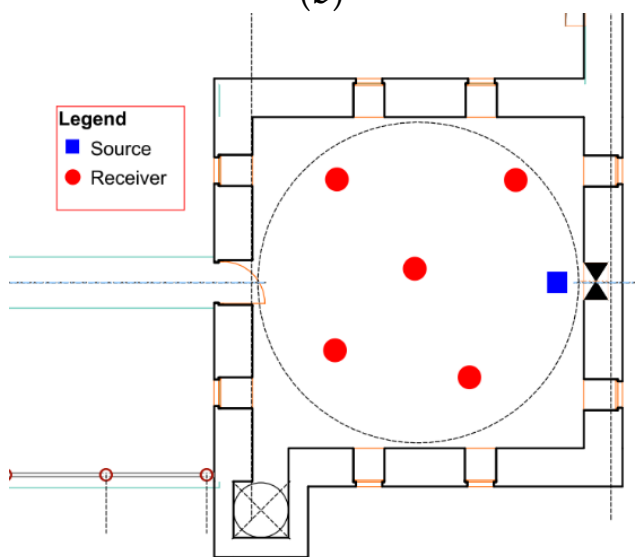

(d)

Figure 14. Scheme of the equipment location during the acoustic surveys inside the selected mosques: Naziresha in Elbasan (a), Lead in Berat (b), Kabalie in Kavaja (c), Et'hem Bey in Tirana (d), Lead in Shkodra (e).

All the acoustic measurements have been carried out in unoccupied conditions. A brief description of the selected acoustic parameters is given below: 
- Early decay time (EDT), measured in seconds, is the time corresponding to $10 \mathrm{~dB}$ from the decay curve of the sound pressure level measured after the interruption of the noise source. The EDT is particularly sensitive to the microphone position.

- Similar to EDT, the reverberation time $\left(T_{20}\right)$ is defined as the time required for the sound pressure level to drop by $60 \mathrm{~dB}$ after the noise source has been switched off. The value of this parameter is in function of the room volume and absorption of the surface area. Since the absorption of materials varies with frequency, the reverberation time varies according to the considered frequency bands.

- Clarity index $\left(\mathrm{C}_{50}\right)$ is a characteristic parameter of speech goodness in a hall. It is a descriptor obtained from the correlation of the emitted energy that reaches the listener within the first 50 milliseconds (including the early reflections) and the energy that arrives in the following instants.

- Definition $\left(\mathrm{D}_{50}\right)$ is a parameter related to the goodness of speech understanding in a room. It is obtained from the correlation of energy that reaches the receiver in the first 50 milliseconds and entire signal energy built up in the room until its total dissipation. The early reflection energy added to the direct sound gives a positive contribution to speech understanding.

- $\quad$ Speech transmission index (STI) represents the degree of amplitude modulation in a speech signal and refers to the distortion of a speech caused by reverberation, echoes and/or background noise. STI values can be comprised between 0 and 1: if the result is $>0.5$, favorable speech conditions occur.

\section{Measured Results}

The recorded data of the IRs have been edited at the beginning by using the software Audacity by having a sample rate equal to $44 \mathrm{kHz}$. Thereafter, the signals have been processed by using the software Dirac. Figures $15-18$ report the main acoustic parameters in the octave frequency bands comprised between $125 \mathrm{~Hz}$ and $4 \mathrm{kHz}$, which were considered as the average results of all the measuring positions.

Figure 15 shows a similar curve trend for all the mosques. The difference at low frequency between the minimum and the maximum value is up to $1.5 \mathrm{~s}$, particularly between Kavaja that shows the lowest values and Shkodra having an EDT equal to $3.0 \mathrm{~s}$ at $125 \mathrm{~Hz}$. This difference is considerably reduced at high frequencies where the values range between $1.0 \mathrm{~s}$ (Berat and Tirana) and $1.3 \mathrm{~s}$ (Shkodra). The lowest values at low frequency are those related to Kavaja, which is the mosque having the smallest room volume, while the highest values across all the frequency bandwidth are related to the Lead Mosque of Shkodra, although it does not have the biggest room volume among all of them. By considering the optimal values of EDT ranging between $1.8 \mathrm{~s}$ and $2.6 \mathrm{~s}$ [22], the outcomes indicate that these values have been achieved between $125 \mathrm{~Hz}$ and $1 \mathrm{kHz}$ only for Berat, Elbasan and Tirana; Shkodra has been found to be exceeding the upper range limit of up to $0.5 \mathrm{~s}$, while Kavaja has the EDT value at $125 \mathrm{~Hz}$ slightly below the lower range limit. At high frequency none of the mosques has EDT values within the optimal range, since all of them are below the lower limit range.

In terms of $\mathrm{T}_{20}$, Figure 16 shows that the trend lines of the mosques are slightly dissimilar each other. In particular, Elbasan has the highest value at $125 \mathrm{~Hz}$, equal to $3.3 \mathrm{~s}$, and the lowest at $4 \mathrm{kHz}$, equal to $1.1 \mathrm{~s}$. Tirana and Berat, by having comparable room volumes, result in a similar line trend. The flattest response of $\mathrm{T}_{20}$ across all the frequency bandwidth is given by Kavaja, to be around $1.8 \mathrm{~s}$ averaged through all frequencies.

In addition, there are few factors that contribute to the $\mathrm{T}_{20}$ results, although these do not emerge from the graph; in particular, not only should the room volume size be considered as the main influence but also the wideness of the squared plan, the height of the dome and the grade of reflectivity of the finish materials applied mainly to the walls and roof $[23,24]$. Therefore, the focus of the sound rays localized at the center of the musalla is considered an acoustic defect typically found in other rooms having similar geometry and architectural organization $[25,26]$. 


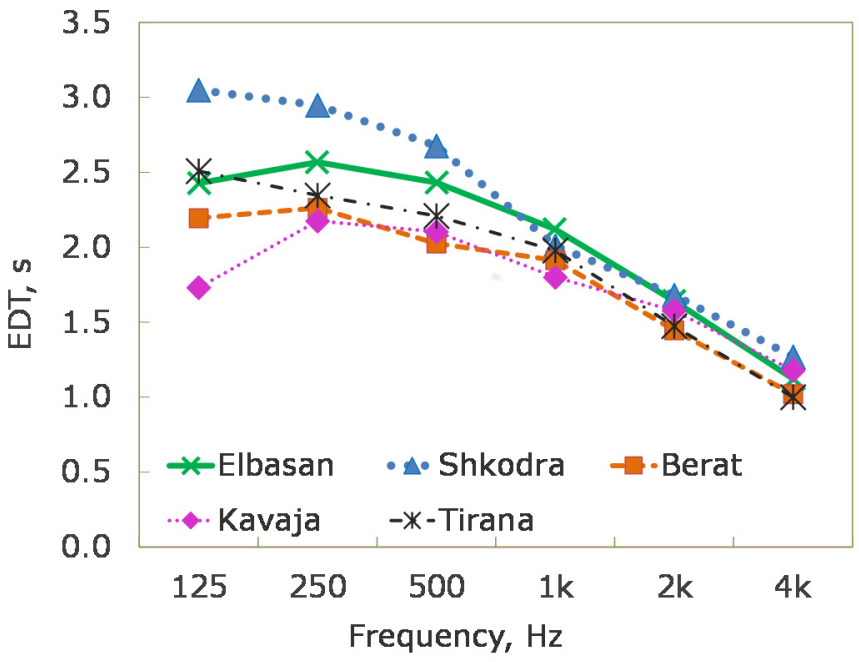

Figure 15. Measured results of early decay time (EDT).

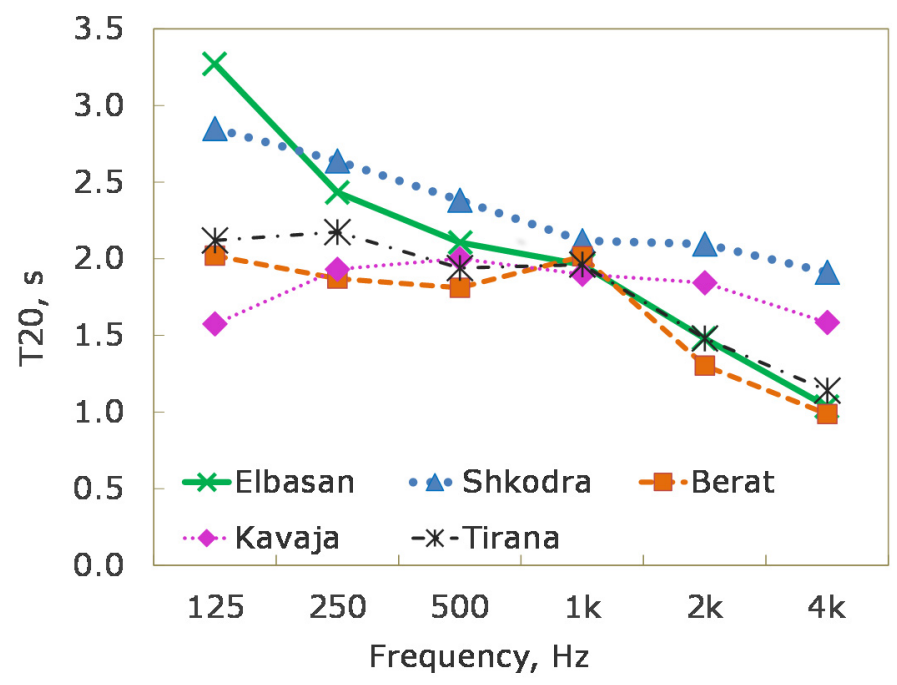

Figure 16. Measured results of reverberation time $\left(\mathrm{T}_{20}\right)$.

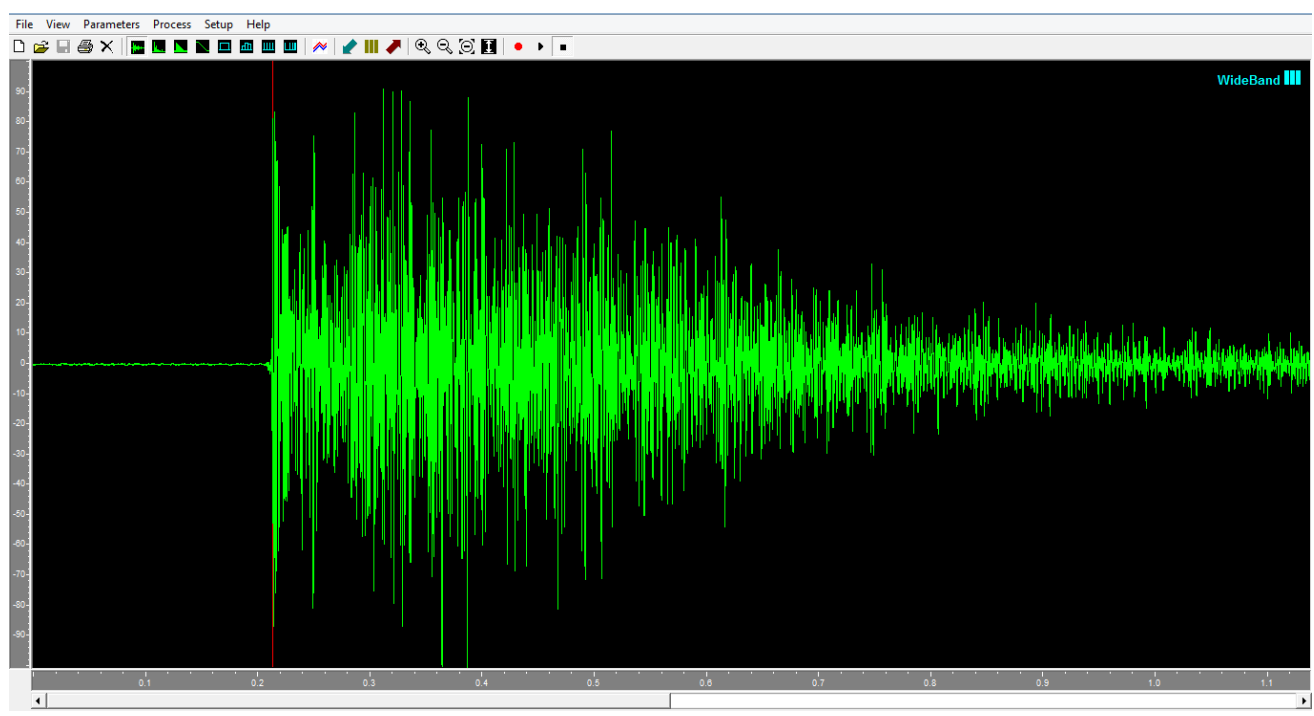

Figure 17. Impulse response measured inside the Naziresha Mosque of Elbasan. 


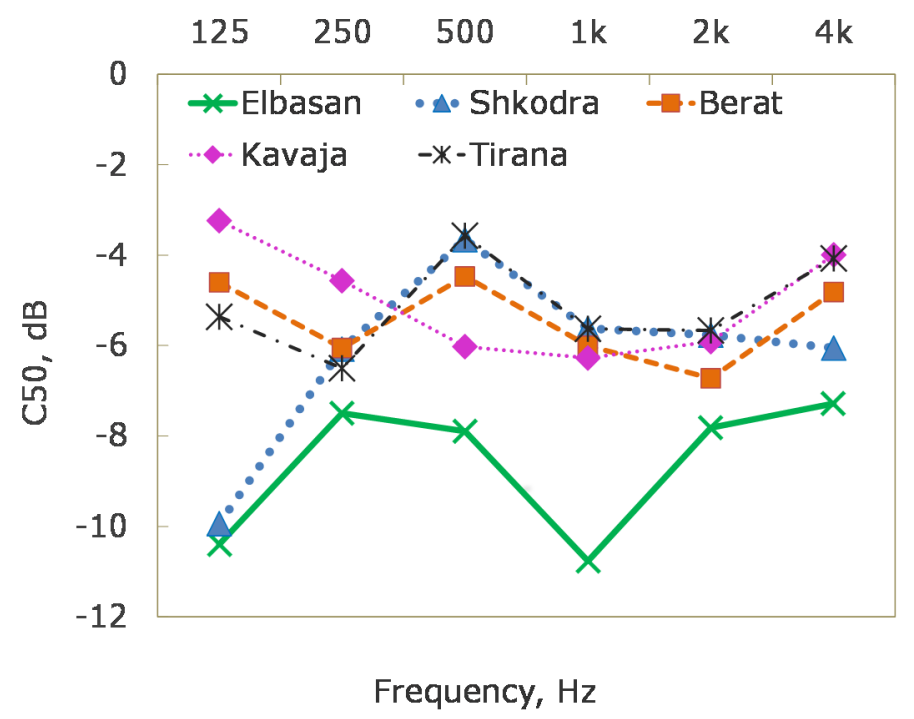

Figure 18. Measured results of clarity index $\left(C_{50}\right)$.

By using the software Dirac, it is possible to analyze the IRs obtained with the measurements. In particular, Figure 17 shows an increase of sound energy after the first reflections such that the trend of the decay curve is not linearly pointing downward but presents a double slope with an initial increase of energy pointing upward and then decreasing to the background noise levels.

This acoustic behavior has been reported only for the Naziresha Mosque of Elbasan, but it is a common aspect found in the other four mosques.

This paper in mainly focused on the evaluation of the acoustic parameters to be in accordance with the ISO 8233-1; investigations on domes' geometry would be developed in a future research study with the support of digital models.

On this basis, the speech transmission index (STI) has been analyzed given the main activity developed inside the musalla centered on prayers and sermons. As such, the STI has been considered as the parameter indicating the degree of amplitude modulation in a speech signal [27]. The STI can be assessed as the level of distortion in speech signals caused by reverberation, echoes and background noise. Although the index can assume values comprised between 0 and 1 , the measured average values in all mosques are found to be fair for speech understanding, based on the STI scale [29] as reported in Table 2.

Table 2. STI scale.

\begin{tabular}{ccccc}
\hline Bad & Poor & Fair & Good & Excellent \\
\hline $0-0.3$ & $0.3-0.45$ & $0.45-0.6$ & $0.6-0.75$ & $0.75-1.0$ \\
\hline
\end{tabular}

The STI values have been obtained with Dirac 4.0 software by Bruel \& Kjaer. In order to understand the STI values, the background noise levels $\left(\mathrm{L}_{\text {Aeq }}\right)$ have been summarized in Table 3 below, related to all the mosques.

Table 3. Background noise levels.

\begin{tabular}{ccccc}
\hline \multicolumn{5}{c}{ A-Weighted Equivalent } \\
\hline Elbasan & Berat & Kavaja & Tirana & Shkodra \\
\hline 51 & 49 & 48 & 56 & 43 \\
\hline
\end{tabular}

Figure 18 shows the results related to the speech clarity index, which are found to be below the optimal target $(>+3 \mathrm{~dB}$ ) [28] for all the mosques. This means that the intelligibility 
of words is fairly poor. The worst $\mathrm{C}_{50}$ has been found in Elbasan, to be up to $13 \mathrm{~dB}$ below the lower range limit, especially at $125 \mathrm{~Hz}$ and $1 \mathrm{kHz}$. The mosques of Tirana, Berat and Kavaja are indicated to have a similar response in terms of $C_{50}$, showing beneficial peaks at $125 \mathrm{~Hz}, 500 \mathrm{~Hz}$ and $4 \mathrm{kHz}$. The results found in Shkodra draw a line trend to be closer to Elbasan at $125 \mathrm{~Hz}$ and close to the other mosques for mid-high frequencies.

In relation to speech clarity, other than the STI parameter, the definition $\mathrm{D}_{50}$ can be also evaluated based on the measured results indicated in Figure 19. Although previous research has determined a good speech definition $\left(D_{50}\right)$ for values higher than $0.5(50 \%)$ [29], the outcomes related to all the mosques show that the values across all the frequency bands fluctuates around $0.2(20 \%)$, which is considered poor.

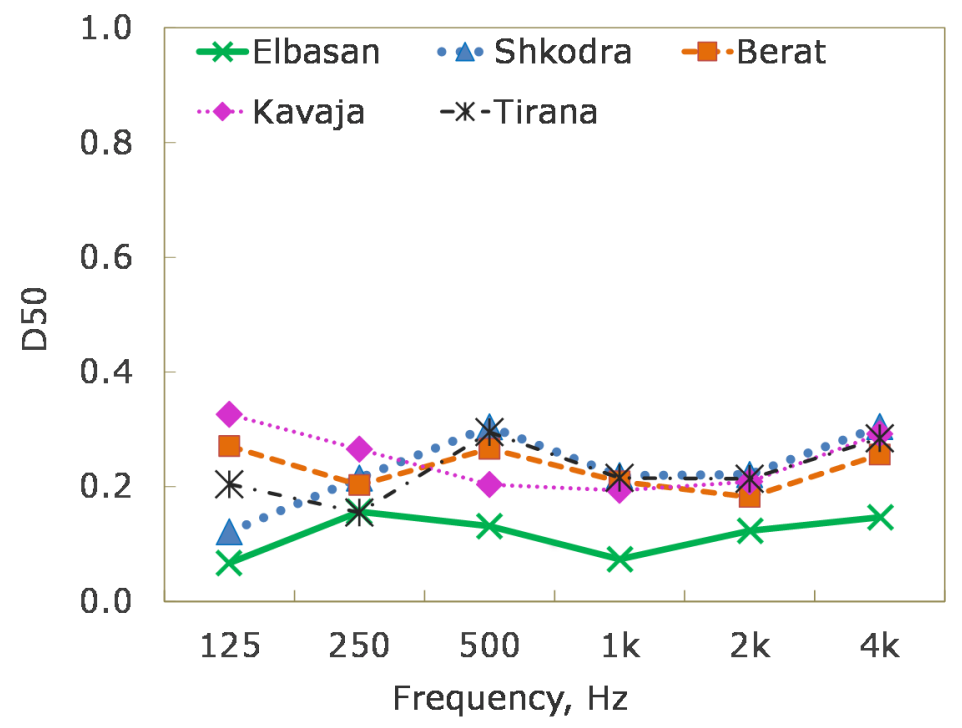

Figure 19. Measured results of definition $\left(D_{50}\right)$.

\section{Conclusions}

The Ottoman mosques herein studied are active places of cult and prayers. The intention of the authors is to highlight the grade of speech understanding of the existing conditions, as this is the main activity performed inside these environments [30,31].

To increase the level of speech definition and move the speech clarity index to be within the optimal range limits, the authors propose acoustic treatments to be applied mainly on the walls [32-36]. A limitation of this study is related to the utilization of the balloon pops, given a certain directivity and a limited spectrum width. In addition, this type of sound source has an unpredictable spectral response, as well as a poor repeatability. All these variabilities, if not properly controlled, can give a low value of signal-to-noise ratio $(\mathrm{S} / \mathrm{N})$, even if this technique is still widely used, especially for small room volumes as it could be a musalla.

In order to avoid invasive or irreversible detriments to these historical buildings, removable transparent micro-perforated panels could represent a solution with a minimal visual impact [37]. As such, the transparency of the new panels would not conceal the beauties of the walls' decorations and, in addition, a specific cavity gap to be left between the panel and the back wall will be also considered.

Future research studies will be focusing on the acoustic simulations with the presence of the proposed absorbing panels, in such a way to improve the listening conditions especially by absorbing the low frequencies and restoring a tonal balance across all the frequency bandwidth [38].

Author Contributions: Conceptualization, S.S., G.I. and A.T.; methodology, G.I., A.T. and G.C.; software, A.B. and G.C.; validation, A.B., G.I. and G.C.; formal analysis, A.B.; investigation, S.S. and G.I.; resources, S.S.; data curation, A.B.; writing-original draft preparation, G.I., A.T. and 
S.S.; writing-review and editing, A.B.; visualization, A.B.; supervision, G.I. and G.C.; project administration, G.I., A.T., S.S. and G.C.; funding acquisition, G.I. and A.T. All authors have read and agreed to the published version of the manuscript.

Funding: This research received no external funding.

Institutional Review Board Statement: Not applicable.

Informed Consent Statement: Not applicable.

Conflicts of Interest: The authors declare no conflict of interest.

\section{References}

1. Abdou, A. Measurement of acoustical characteristics of mosques in Saudi Arabia. J. Acoust. Soc. Am. 2003, 113, 1505-1517. [CrossRef] [PubMed]

2. Hammad, R.N.S. RASTI Measurements in Mosques in Amman, Jordan. Appl. Acoust. 1990, 30, 335-345. [CrossRef]

3. Elkhateeb, A.; Adas, A.; Attia, M.; Balila, Y. The acoustics of Masjids, why they differ from the classical speech rooms. In Proceedings of the 22nd International Congress for Sound and Vibration (ICSV), Florence, Italy, 15-16 July 2015.

4. Kassim, D.; Putra, A.; Nor, M.J. The acoustical characteristics of the Sayyidina Abu Barak Mosque, UTeM. J. Eng. Sci. Technol. 2015, 10, 97-110.

5. Khan, H.U. The Mosque: History, Architectural Development \& Regional Diversity, Paperback ed.; Thames \& Hudson Ltd.: London, $\mathrm{UK}, 2002$.

6. Kahera, A.; Abdumalik, L.; Anz, C. Design Criteria for Mosques and Islamic Centers, 1st ed.; Elsevier: Oxford, UK, 2009.

7. Kuran, A. The Mosque in Early Ottoman Architecture; The University of Chicago Press Ltd.: Chicago, IL, USA, 1968.

8. Kuban, D.A. Symbol of Ottoman Architecture: The Süleymaniye in Ottoman Architecture; Antique Collectors' Club: Suffolk, UK, 2010; pp. 277-294.

9. Wikimedia. Available online: https://upload.wikimedia.org/wikipedia/commons/a/a6/Elbasan_-_Naziresha_Mosque_\%2 8by_Pudelek\%29.JPG (accessed on 17 September 2021).

10. Wikimedia. Available online: https://upload.wikimedia.org/wikipedia/commons/7/71/Xhamia_e_Plumbit_Berat.jpg (accessed on 17 September 2021).

11. Wikimedia. Available online: https://upload.wikimedia.org/wikipedia/commons/8/89/Kavaja_Mosque.jpg (accessed on 17 September 2021).

12. Wikimedia. Available online: https://upload.wikimedia.org/wikipedia/commons/4/4b/Et\%27hem_Bey_Mosque_\%26_Clock_ tower.jpg (accessed on 17 September 2021).

13. Wikimedia. Available online: https://upload.wikimedia.org/wikipedia/commons/6/6e/Albania_Lead_Mosque_02.JPG (accessed on 17 September 2021).

14. Pätynen, J.; Katz, B.F.G. Investigation on the balloon as an impulse source. J. Acoust. Soc. Am. 2011, 129, EL27-EL33. [CrossRef] [PubMed]

15. Fausti, P.; Farina, A. Acoustic measurements in opera houses: Comparison between different techniques and equipment. J. Sound Vib. 2000, 232, 213-229. [CrossRef]

16. Farina, A. Brahma Microphones-Ambisonics microphone. Available online: www.brahmamic.com (accessed on 8 July 2021 ).

17. Available online: http:/ / pcfarina.eng.unipr.it/Public/Brahma/Brahmavolver/ (accessed on 26 June 2021).

18. Gomez-Agustina, L.; Bernard, J. Practical and technical suitability perceptions of sound sources and test signals used in room acoustic testing. In Proceedings of the 48th International Congress and Exhibition on Noise Control Engineering Noise Control Engineering Inter-Noise, Madrid, Spain, 16-19 June 2019.

19. Gomez-Agustina, L.; Vazquez-Barrera, P. Repeatability of the balloon pop as a sound source in a room. In Proceedings of the Institute of Acoustics, London, UK, 5-9 October 2020; Volume 42.

20. Part 1: Performance Spaces. ISO 3382-1: Acoustics-Measurement of Room Acoustic Parameters; ISO: Geneva, Switzerland, 2009.

21. Abdou, A.A. Assessment of mosque acoustics for speech intelligibility employing impulse response measurements. In Proceedings of the 15th International Congress Sound Vibration, Daejeon, South Korea, 6-10 July 2008.

22. Jordan, V.L. Acoustical criteria for auditoriums and their relation to model techniques. J. Acoust. Soc. Am. 1970, 47, 408-412. [CrossRef]

23. Zühre, S.G.; Mehmet, Ç. Impact of design decisions on acoustical comfort parameters: Case study of Doğramacızade Ali Paşa Mosque. Appl. Acoust. 2013, 74, 834-844.

24. Alic, E.; Ozcevik Bilen, A. Determination of the characteristics of contemporary Turkish mosque and its acoustic properties. In Proceedings of the 23rd International Congress Acoustics, Aachen, Germany, 9-13 September 2019; pp. 3983-3990.

25. Abdelazeez, M.K.; Hammad, R.N.; Mustafa, A. Acoustics of King Abdullah Mosque. J. Acoust. Soc. Am. 1991, 90, 1441-1445. [CrossRef]

26. Elkhateeb, A.; Eldakdoky, S. The acoustics of Mumluk masjids: A case study of Iwan-type masjids in Cairo. Appl. Acoust. 2021, 178, 107988. [CrossRef] 
27. Peer, I.; Rafaely, B.; Zigel, Y. Room acoustics parameters affecting speaker recognition degradation under reverberation. In Proceedings of the 2008 Hands-Free Speech Communication and Microphone Arrays (HSCMA), Trento, Italy, 6-8 May 2008; pp. 136-139.

28. Reichardt, W.; Abel Alim, O.; Schmidt, W. Definition and basis of making an objective evaluation to distinguish between useful and useless clarity defining musical performances. Acta Acust. 1975, 3, 126-137.

29. Thiele, R. Richtungsverteilungs und zeitfolge del schallruckewurfe in raumen. Acta Acust. 1953, 3, $291-302$.

30. Aleshkin, V.; Schirjetsky, C.; Subbotkin, A. Estimating sound absorption coefficient of prayers in mosques. Akustika 2019, 32, 227-230. [CrossRef]

31. Ciaburro, G.; Iannace, G.; Lombardi, I.; Trematerra, A. Acoustic design of ancient buildings: The odea of Pompeii and Posillipo. Buildings 2020, 10, 1-16. [CrossRef]

32. Tronchin, L.; Merli, F.; Manfren, M.; Nastasi, B. The sound diffusion in Italian Opera Houses: Some examples. Build. Acoust. 2020, 27, 333-355. [CrossRef]

33. Sukaj, S.; Ciaburro, G.; Iannace, G.; Lombardi, I.; Trematerra, A. The Acoustics of the Benevento Roman Theatre. Buildings 2021, 11, 212. [CrossRef]

34. Iannace, G.; Ciaburro, G.; Trematerra, A.; Foglia, C. Acoustic correction of a renaissance period hall. Can. Acoust. - Acoust. Can. $2019,47,57-66$.

35. Iannace, G.; Berardi, U.; De Rossi, F.; Mazza, S.; Trematerra, A.; Ciaburro, G. Acoustic enhancement of a modern church. Buildings 2019, 9, 83. [CrossRef]

36. Oldham, D.J.; Elkhateeb, A.E. The absorption characteristics of Muslim worshippers. Build. Acoust. 2008, 15, 335-348. [CrossRef]

37. Putra, A.; Hafizah, D.; Yaakob, M.Y.; Nor, M.J.M. Study on the use of micro-perforated panel to improve acoustic performance in mosque. Appl. Mech. Mater. 2013, 393, 971-975. [CrossRef]

38. Cox, T.J.; D'Antonio, P. Acoustic Absorbers and Diffusers: Theory, Design and Application, 3rd ed.; CRC Press: Boca Raton, FL, USA, 2004. 